\title{
COVID-19 preventive interventions for high-risk pregnant women and preschool children: a rehearsal for the baby boomers' old-age pandemic?
}

\section{Interventions préventives pour les femmes enceintes et les jeunes enfants à risque pendant et après la COVID-19: une préparation à la pandémie du vieillissement des baby-boomers?}

\author{
Richard E. Tremblay ${ }^{1,2}$ \\ Received: 24 March 2021 / Accepted: 8 September 2021 / Published online: 28 January 2022 \\ (c) The Author(s), under exclusive licence to The Canadian Public Health Association 2021
}

\begin{abstract}
A large research-based consensus was achieved over the past 30 years concerning the importance of prenatal and early childhood development: Preventive interventions are needed early in life because physical and psychological problems during pregnancy and early childhood often lead to serious physical, psychological, educational, and social problems throughout the life course. These problems are also transmitted to the next generation. The COVID-19 pandemic is likely to have increased the number of families who need these early-life preventive interventions. Without intensive support, children from high-risk families are likely to fail in school, to have serious physical and mental health problems, and to reproduce another generation of children with similar physical, cognitive, and mental health problems. We underline the need to: (1) assess the extent of the COVID-19 damage on pregnant women and on their spouses, as well as on the families with preschool children; (2) help service providers identify the state-of-the art services they should implement; (3) assess the implementation of these services; and (4) help service providers maintain highly effective interventions. For the next 20 to 30 years at least, governments will be under intense pressure to invest massively in the health and care of the baby boomers. We are thus facing abysmal health care and retirement costs for the next 3 decades. Governments should be pressured to substantially invest in the support of pregnant women and preschool children, rather than in the sustained quality of life of the aging baby boomers.
\end{abstract}

\section{Résumé}

Un consensus important de la recherche au cours des 30 dernières années souligne l'impact de la période prénatale et de la petite enfance sur le développement à long terme. Des mesures préventives doivent être mises en place dès le jeune âge. Les problèmes physiques et/ou psychologiques pendant la grossesse et la petite enfance mènent souvent à de graves problèmes physiques, psychologiques, académiques, et sociaux la vie durant. Ces problèmes sont souvent transmis à la génération suivante. La pandémie de la COVID-19 augmentera vraisemblablement le nombre de familles nécessitant des interventions préventives précoces. Sans ce soutien intensif, ces enfants seront à risque de décrochage scolaire, de troubles de santé physique et mentale graves, et de transmission intergénérationnelle de problèmes semblables. L'impact de la pandémie se ferait ainsi ressentir par la société jusqu'au siècle prochain. D'autre part, l'impact de la pandémie sur nos aînés a mis en évidence le problème de la qualité des soins pour les personnes âgées. Il faudra donc faire pression auprès des gouvernements pour que, malgré les autres urgences, ils investissent de façon importante pour soutenir les femmes enceintes et les enfants d'âge préscolaire.

Keywords Prenatal development · Early childhood development · Preventive interventions · Pregnancy · Intergenerational transmission $\cdot$ COVID-19 $\cdot$ Senior citizens' generativity

Extended author information available on the last page of the article 
Mots-clés Développement prénatal · développement à la petite enfance $\cdot$ interventions préventives $\cdot$ grossesse . transmission intergénérationnelle · COVID-19 · générativité des personnes âgées

A large research-based consensus was achieved over the past 30 years concerning the importance of prenatal and early childhood development: Preventive interventions are needed early in life because children with physical and psychological problems during early childhood are at high risk of serious physical, psychological, educational, and social problems throughout their lives (Caspi et al., 2016; Hayward et al., 2020; Orri et al., 2020, 2021).

These high-risk children are largely over-represented in families of parents who had similar problems during their own early development (Akhtar-Danesh \& Landeen, 2007). For example, a recent Canadian study of 315,811 kindergarten children from 2052 neighbourhoods in Canada (Webb et al., 2020) reported that kindergarten children living in low socioeconomic neighbourhoods were at higher risk of having important problems in the following domains: physical health and well-being, social competence, emotional maturity, language and cognitive development, communication skills, and general knowledge.

There is strong evidence that these health and educational problems in kindergarten were often preceded by developmental problems during pregnancy and infancy (Galéra et al., 2011; Tremblay et al., 2018). Pregnant women with low levels of education are more at risk of physical and mental health problems (Akhtar-Danesh \& Landeen, 2007). Their husbands are more likely to have similar mental health problems (Nordsletten et al., 2016), and these families are also less likely to provide the physical, emotional, and intellectual environments needed to foster their children's development (Orri et al., 2019). The intergenerational transmission of physical, intellectual, emotional, educational, and social problems will generally follow its dramatic course if we do not provide these young parents with the support needed during their first pregnancy and during the early development of their children.

It is important to highlight this body of research with reference to the COVID-19 pandemic because the consequences of the pandemic have most likely worsened the problems of these young parents and their children, and thus increased the gap between their children and the children of parents who were more successful in school and on the work market (Matar et al., 2021; Prime et al., 2020).

\section{Effective preventive interventions during pregnancy and early childhood}

Fortunately, there is a relatively long tradition of successful experiments in which high-risk families were provided with intensive support during pregnancy and during their children's early childhood development (Côté et al., 2018). For example, young pregnant women with a history of psychosocial adjustment problems, who received intensive support from pregnancy until their child's second year after birth, significantly increased the quality of their maternal care, compared with a control group. More importantly, by the end of adolescence, their children had a higher IQ, performed better in mathematics, finished high school, and needed significantly less public services (Kitzman et al., 2019; Olds et al., 2019).

Providing high-quality child care from infancy to school entry also showed short-term, lifelong, and intergenerational benefits for the children of poor parents, as well as for the children of parents with a history of psychosocial adjustment problems (Heckman \& Karapakula, 2019; Larose et al., 2019; Webster-Stratton, 1998).

\section{Early childhood interventions during and after COVID-19}

The COVID-19 pandemic provides an exceptional opportunity to convince professionals and policy makers to implement and monitor the impact of these state of the art interventions. A major effort to give long-term support to today's at-risk pregnant women, their spouses, and their offspring would have major enduring social, health, and economic benefits. The future of our national health and wealth depends on the successful implementation of the support that will be given to today's young high-risk families. Without intensive support, their children are at high risk of failing in school, of having serious physical and mental health problems, and of reproducing another generation of children with similar physical, cognitive, and mental health problems. Thus, the negative impacts of the pandemic are likely to be felt by the whole of society well into the next century.

From a research perspective, the first step we need to take is to assess the extent of the COVID-19 damage on pregnant women, on their spouses, as well as on the families with preschool children. There is a strong possibility that COVID-19 is substantially increasing the number of high-risk children through its negative impacts on the young adults who became or are becoming parents during the pandemic (Cost et al., 2021; Matar et al., 2021; Prime et al., 2020).

The second step should be to help service providers identify the state-of-the-art services they should implement. The third step should be to assess the implementation of these services. Finally, in the fourth step, we need to assess the short-, medium-, and long-term impacts of these services to help service providers maintain highly effective interventions. 
This systematic approach to help the most at-risk children during and after the COVID-19 pandemic will: (a) provide continuous feedback on the effects of the services that will be implemented; (b) provide the information needed to make corrections; and (c) provide a model for the planning and assessment of other services.

\section{A multigenerational perspective}

The COVID-19 pandemic is clearly showing that we need to develop a systematic approach to crises which are likely to have negative impacts on a whole generation of infants, children, adolescents, and young adults. The present pandemic has convinced governments that they need to invest billions of dollars to stimulate the economy. They also need to understand that a large proportion of these dollars need to be invested in stimulating the development of their future citizens, especially those who were born in the worst circumstances and are most likely to suffer from these circumstances throughout their lives and their own children's lives. This suffering will most likely have intergenerational negative impacts on the economy and on the quality of life if we do not invest in the most-at-risk children and their families.

Choosing at-risk pregnant women, infants, and preschool children as a national priority is not a natural tendency for governments, especially during a pandemic where grandparents and great-grandparents constitute the majority of those who are dying.

However, we need to seriously consider the following question: What choice would grandparents and great-grandparents make if they had to choose between investing in the quality of their remaining years versus investing in the quality of the lives of their grandchildren and great-grandchildren?

Government investments in the economy are clearly needed to ensure citizens' quality of life. However, there is also a wide consensus that one of the best long-term investments in the economy is investment in children's brain development, which has been shown to be at its most sensitive period during pregnancy and early childhood (Heckman, 2006; Zhou et al., 2021; Zou et al., 2019). Such investments involve intensive support to the most at-risk families during pregnancy and early childhood, including early support to pregnant women and high-quality child-care and preschool education, as well as support to parents' employment.

\section{Implications for policy and practice}

We need to quickly realize that, beyond the COVID-19 pandemic, we are facing a unique and very serious demographic challenge, which also coincides with the climate crisis. The baby boom, which started at the end of the 1940s and lasted until the early 1960s, was followed by a substantial and enduring decrease in the number of births. The older baby boomers are now reaching their mid-70s. Twenty years ago, they were among the first humans to be able to start retiring at 55 years of age. They will be followed by an increasing number of retired women and men for the next two decades. Furthermore, their life expectancy has substantially increased compared to the life expectancy of their own parents (Decady \& Greenberg, 2014).

Their children's, grandchildren's, and great-grandchildren's lives are unlikely to be as prosperous. Indeed, the substantially smaller number of children, grandchildren, and great-grandchildren that the baby boomers fostered will have to financially support their parents' and grandparents' historically long retirement due to both earlier retirement and increasing life expectancy. The COVID-19 impact on older citizens and on the quality of homes for older citizens clearly highlights the fact that for the next 20 to 30 years at least, governments will be under intense pressure to invest large parts of their budgets on the very long retirement of the baby boomers.

Who will put pressure on governments to invest substantially in the support of pregnant women and preschool children, rather than in the quality of life of the aging baby boomers? We can hope that the baby boomers have discovered or will discover the moral value of "generativity": investing in those who will outlast ourselves (Erikson, 1959). But we will also need the science of public health to keep governments informed on the best preventive services needed to foster the healthy development of the children born in high-risk families.

\section{Interventions préventives pour les femmes enceintes et les jeunes enfants à risque pendant et après la COVID-19 : une préparation à la pandémie du vieillissement des baby-boomers?}

Un consensus important de la recherche au cours des 30 dernières années met en évidence les impacts à long terme du développement pendant la période prénatale et la petite enfance. Des mesures préventives doivent être implantées dès le jeune âge, car les enfants atteints de troubles physiques ou psychologiques s'avèrent être à risque de graves problèmes sur le plan physique, psychologique, académique, et social tout au long de leur vie (Caspi et al., 2016; Hayward et al., 2020; Orri et al., 2020, 2021).

Les jeunes enfants à risque élevé sont surreprésentés dans les familles de parents qui ont eux-mêmes vécu des difficultés de développement (Akhtar-Danesh \& Landeen, 
2007). À titre d'exemple, une étude pancanadienne menée récemment auprès de 315811 enfants à la maternelle, dans 2052 quartiers différents (Webb et al., 2020), montre que les enfants provenant de quartiers désavantagés sur le plan socioéconomique étaient à risque plus élevé de difficultés dans les domaines suivants : santé physique et bien-être, compétence sociale, maturité émotionnelle, langage, développement cognitif, communication, et connaissances générales.

Les études du développement des enfants montrent que les problèmes observés à la maternelle découlent souvent des problèmes du développement au prénatal et/ou à la petite enfance (Galéra et al., 2011; Tremblay et al., 2018). Les femmes enceintes qui ont un faible niveau d'éducation sont plus à risque de problèmes de santé physique et mentale (Akhtar-Danesh \& Landeen, 2007). Leurs conjoints ont tendance à souffrir de problèmes de santé mentale similaires (Nordsletten et al., 2016), et ces familles sont souvent moins en mesure de créer un environnement physique, émotionnel, et intellectuel propice au développement optimal de leurs enfants (Orri et al., 2019). La transmission intergénérationnelle de problèmes physiques, intellectuels, émotionnels, académiques, et sociaux continuera généralement de suivre son cours si l'on ne fournit pas aux jeunes parents le soutien nécessaire, dès la première grossesse, et tout au cours du développement de leurs enfants en bas âge.

Il est important de souligner ce corpus de recherche quand on fait référence à la pandémie de la COVID-19. Les conséquences de la pandémie ont vraisemblablement augmenté les troubles des jeunes parents et de leurs enfants et ce faisant, élargi l'écart entre les enfants de familles désavantagées et les enfants dont les parents ont un niveau académique et économique plus aisé (Matar et al., 2021; Prime et al., 2020).

\section{Interventions préventives jugées efficaces pendant la grossesse et la petite enfance}

La tradition relativement longue d'essais randomisés offre heureusement des interventions qui permettent aux familles à risque de profiter d'un soutien intensif pendant la grossesse et pendant la petite enfance (Côté et al. 2018). En particulier, ces essais randomisés ont montré que les jeunes femmes enceintes qui avaient des difficultés d'adaptation psychosociale, et qui ont bénéficié d'un soutien intensif pendant la grossesse jusqu'à ce que leurs enfants aient deux ans, ont donné à leurs enfants une qualité de soins maternel supérieure à celle du groupe témoin. De plus, à la fin de l'adolescence, leurs enfants avaient un Quotient Intellectuel plus élevé, ils avaient de meilleures notes en mathématiques, terminaient leurs études secondaires, et étaient moins dépendants des services publiques (Kitzman et al., 2019; Olds et al., 2019).
Les expériences de mise en place de centres de la petite enfance de qualité, entre la petite enfance et l'école maternelle, montrent également des avantages pour les enfants de parents pauvres ou avec des antécédents de difficultés d'adaptation psychosociale. Ces avantages ont été observés à court terme, tout au cours de leur vie, et pour la génération suivante (Heckman \& Karapakula, 2019; Larose et al., 2019; Webster-Stratton, 1998).

\section{Interventions en petite enfance pendant et après la COVID-19}

La pandémie de la COVID-19 offre une occasion exceptionnelle de persuader les professionnels et les décideurs d'implanter des interventions de pointe et évaluer leurs impacts. Un effort particulier pour soutenir à long terme les femmes enceintes à risque, leurs conjoints, et leurs enfants, pourrait avoir des impacts considérables sur le plan social, médical, et économique. Notre avenir national en santé et en richesse dépend de la mise en œuvre dès aujourd'hui d'un soutien intensif aux familles à risque, pour éviter que les enfants de ces familles aient des problèmes de décrochage scolaire, de santé physique, de santé mentale, et de transmission de problèmes physiques, cognitifs et psychologiques similaires à la génération suivante. L'impact négatif de la pandémie risque d'être ressenti par la société entière jusqu'au siècle prochain, si nous n'offrons pas ces services aux familles à haut risque.

Dans une perspective de recherche, le premier volet devrait être d'évaluer l'étendue des conséquences négatives de la pandémie de la COVID-19 sur les femmes enceintes, sur leurs conjoints, et sur les familles avec des enfants en bas âge. Il est fort probable que la pandémie aura augmenté de façon substantielle le nombre d'enfants à risque, ne serait-ce que par ses effets sur les jeunes adultes qui deviendront, ou sont déjà devenus parents pendant la pandémie (Cost et al., 2021; Matar et al., 2021; Prime et al., 2020).

Le deuxième volet devrait être d'aider les prestataires de services à identifier les services novateurs et de qualité qu'ils ont avantage à implanter. Le troisième volet devrait évaluer la mise en œuvre de ces services. Et finalement, le quatrième volet devrait évaluer les impacts à court, moyen, et long terme, afin d'aider les prestataires de services à offrir les interventions les plus efficaces.

Cette approche systématique pour les enfants les plus à risque pendant et après la pandémie servira à : a) offrir une rétroaction continue sur l'impact des services implantés; b) fournir les informations nécessaires à l'amélioration des interventions; et c) établir un modèle pour la planification et l'évaluation d'autres services. 


\section{Perspective multigénérationnelle}

La pandémie de la COVID-19 démontre nettement la nécessité d'élaborer une approche systématique aux crises qui ont des impacts négatifs sur toute une génération de nourrissons, d'enfants, d'adolescents, et de jeunes adultes. Les gouvernements ont répondu à la pandémie par un investissement de milliards de dollars pour maintenir et stimuler l'économie. Il est maintenant temps d'investir des sommes équivalentes pour stimuler le développement de nos futurs citoyens, particulièrement les enfants nés dans les pires circonstances, et qui sont les plus à risque de souffrir de ces circonstances tout au long de leur vie et celle de leurs enfants. Cette souffrance aura vraisemblablement des impacts négatifs intergénérationnels sur l'économie et sur la qualité de vie, si nous n'investissons pas immédiatement pour le soutien des enfants et des familles les plus à risque.

Les gouvernements n'ont pas une tendance naturelle à mettre les femmes enceintes, les nourrissons, et les petits enfants en priorité de l'ordre du jour, particulièrement lors d'une pandémie dont les conséquences les plus évidentes sont le décès des grands-parents et des arrière-grands-parents. Cependant, il faut se poser la question suivante : $\mathrm{Si}$ les grandsparents et les arrière-grands-parents qui ont survécu avaient le choix d'investir dans leur qualité de vie ou dans la qualité de vie de leurs enfants et petits-enfants, que choisiraient-ils?

Les investissements de la part du gouvernement qui visent à soutenir l'économie sont essentiels pour maintenir la qualité de vie de tous les citoyens. Il est maintenant démontré qu'un des meilleurs investissements économiques à long terme est le soutien du capital humain, c'est-à-dire, le développement du cerveau des jeunes citoyens. Nous savons également que ce cerveau est particulièrement sensible aux effets de l'environnement pendant la grossesse et la petite enfance (Heckman, 2006; Zhou et al. 2021; Zou et al., 2019). Un tel investissement implique le soutien intensif aux familles les plus à risque pendant cette période, c'est-àdire, le soutien des femmes dès le début de leurs grossesses, l'accès à l'éducation préscolaire de qualité et le soutien aux parents sur le marché du travail.

\section{Conséquences pour les politiques et la pratique}

Il faut se rendre compte rapidement qu'à part la pandémie de la COVID-19, nous faisons face à un changement démographique unique et majeur, qui coïncide aussi avec la crise climatique. Le «baby-boom » qui a commencé à la fin des années 1940 et qui a continué jusqu'au début des années 1960, fut suivi d'une diminution substantielle et continue du taux de natalité.
Les plus âgés des baby-boomers vont bientôt avoir 75 ans. Il y a 20 ans, ils étaient les premiers à pouvoir prendre leur retraite à l'âge de 55 ans. Ils seront suivis d'un nombre grandissant d'hommes et de femmes retraités pendant les deux prochaines décennies. De plus, l'espérance de vie a considérablement augmenté par rapport à celle de leurs propres parents (Decady \& Greenberg, 2014).

Sur le plan économique, les enfants, petits-enfants, et arrière-petits-enfants des baby-boomers seront fort probablement moins aisés que leurs aînés, car un plus grand nombre de personnes âgées dépendra d'un plus petit nombre de descendants pour les soutenir financièrement, et ce, pendant une plus longue période de vie, due à la retraite anticipée et à une espérance de vie prolongée. L'impact observé de la COVID-19 sur les personnes âgées et sur la qualité des résidences pour aînés met clairement en évidence le fait que pour les prochains 20-30 ans, le gouvernement sera sous pression intense d'investir une grande partie de son budget pour soutenir la longue retraite et les soins médicaux dispendieux des baby-boomers.

Qui fera pression auprès des gouvernements pour investir de façon substantielle dans le soutien de qualité pour les femmes enceintes et les jeunes enfants, plutôt que dans la qualité de vie des baby-boomers vieillissants? On peut espérer que les baby-boomers ont découvert ou découvriront la valeur morale de la "générativité » : investir dans ceux qui nous survivront (Erikson, 1959). Nous aurons également besoin de la science de la santé publique pour informer les gouvernements sur les meilleurs services de prévention afin de favoriser le sain développement des enfants de parents qui ont une histoire de difficultés d'adaptation.

Acknowledgement/ Remerciement The author thanks Danielle Buch, Medical Writer, Research, for translation of the article. / L'auteur remercie Mme Danielle Buch, rédactrice médicale et scientifique, pour la traduction de l'article.

Author contributions Richard E. Tremblay wrote the article.

Data availability NA.

Code availability NA.

\section{Declarations}

Conflict of interest The author declares that he has no conflict of interest.

Ethics approval NA

Consent to participate NA

Consent for publication NA 


\section{References/Références}

Akhtar-Danesh, N., \& Landeen, J. (2007). Relation between depression and sociodemographic factors. International Journal of Mental Health Systems, 1, 4.

Caspi, A., Houts, R. M., Belsky, D. W., Harrington, H., Hogan, S., Ramrakha, S., et al. (2016). Childhood forecasting of a small segment of the population with large economic burden. Nature Human Behaviour, 1, 0005.

Cost, K. T., Crosbie, J., Anagnostou, E., Birken, C. S., Charach, A., Monga, S., Kelley, E., Nicolson, R., Maguire, J. L., Burton, C. L., Schachar, R. J., Arnold, P. D., \& Korczak, D. J. (2021). Mostly worse, occasionally better: impact of COVID-19 pandemic on the mental health of Canadian children and adolescents. European Child \& Adolescent Psychiatry, 1-14.

Côté, S. M., Orri, M., Tremblay, R. E., \& Doyle, O. (2018). A multicomponent early intervention program and trajectories of behavior, cognition, and health. Pediatrics, 141(5), 1-14. (e20173174).

Decady, Y., \& Greenberg, L. (2014). Ninety years of changes in life expectancy: Health at a glance. Statistics Canada Catalogue no. 82-624-x.

Erikson, E. H. (1959). Identity and the life cycle: Selected papers. International Universities Press.

Galéra, C., Côté, S. M., Bouvard, M. P., Pingault, J. B., Melchior, M., Michel, G., . . . Tremblay, R. E. (2011). Early risk factors for hyperactivity-impulsivity and inattention trajectories from age 17 months to 8 years. Archives of General Psychiatry, 68(12), 1267-1275

Hayward, D. A., Pomares, F., Casey, K. F., Ismaylova, E., Levesque, M., Greenlaw, K., . . . Booij, L. (2020). Birth weight is associated with adolescent brain development: A multimodal imaging study in monozygotic twins. Human Brain Mapping, 41(18), 5228-5239.

Heckman, J. J. (2006). Skill formation and the economics of investing in disadvantaged children. Science, 312(5782), 1900-1902.

Heckman, J. J., \& Karapakula, G. (2019). Intergenerational and intragenerational externalities of the Perry Preschool Project. NBER Working Paper No. 25889. National Bureau of Economic Research.

Kitzman, H., Olds, D. L., Knudtson, M. D., Cole, R., Anson, E., Smith, J. A., . . . Conti, G. (2019). Prenatal and infancy nurse home visiting and 18-year outcomes of a randomized trial. Pediatrics, 144(6), 1-13 (e20183876).

Larose, M. P., Ouellet-Morin, I., Vitaro, F., Geoffroy, M. C., Ahun, M., Tremblay, R. E., \& Côté, S. M. (2019). Impact of a social skills program on children's stress: A cluster randomized trial. Psychoneuroendocrinology, 104, 115-121.

Matar, R., Alrahmani, L., Monzer, N., Debiane, L. G., Berbari, E., Fares, J., . . . Murad, M. H. (2021). Clinical presentation and outcomes of pregnant women with coronavirus disease 2019: A systematic review and meta-analysis. Clinical Infectious Diseases, 72(3), 521-533.

Nordsletten, A. E., Larsson, H., Crowley, J. J., Almqvist, C., Lichtenstein, P., \& Mataix-Cols, D. (2016). Patterns of nonrandom mating within and across 11 major psychiatric disorders. JAMA Psychiatry, 73(4), 354-361.

Olds, D. L., Kitzman, H., Anson, E., Smith, J. A., Knudtson, M. D., Miller, T., .. . Conti, G. (2019). Prenatal and infancy nurse home visiting effects on mothers: 18-year follow-up of a randomized trial. Pediatrics, 144(6), 1-17 (e20183889).

Orri, M., Pingault, J., Turecki, G., Nuyt, A., Tremblay, R., Côté, S., \& Geoffroy, M. (2021). Contribution of birth weight to mental health, cognitive and socioeconomic outcomes: Two-sample Mendelian randomisation. The British Journal of Psychiatry, 219(3), 507-514.

Orri, M., Russell, A. E., Mars, B., Turecki, G., Gunnell, D., Heron, J., . . Geoffroy, M. C. (2020). Perinatal adversity profiles and suicide attempt in adolescence and young adulthood: Longitudinal analyses from two 20-year birth cohort studies. Psychological Medicine.

Orri, M., Tremblay, R. E., Japel, C., Boivin, M., Vitaro, F., Losier, T., ... Côté, S. M. (2019). Early childhood child care and disruptive behavior problems during adolescence: A 17-year populationbased propensity score study. Journal of Child Psychology and Psychiatry, 60(11), 1174-1182.

Prime, H., Wade, M., \& Browne, D. T. (2020). Risk and resilience in family well-being during the COVID-19 pandemic. The American Psychologist, 75(5), 631-643.

Tremblay, R. E., Vitaro, F., \& Côté, S. M. (2018). Developmental origins of chronic physical aggression: A bio-psycho-social model for the next generation of preventive interventions. Annual Review of Psychology, 69, 383-407.

Webb, S., Duku, E., Brownell, M., Enns, J., Forer, B., Guhn, M., . . . Janus, M. (2020). Sex differences in the socioeconomic gradient of children's early development. SSM - Population Health, 10, 100512.

Webster-Stratton, C. (1998). Preventing conduct problems in Head Start children: Strengthening parenting competencies. Journal of Consulting and Clinical Psychology, 66(5), 715-730.

Zhou, J., Baulos, A., Heckman, J. J., \& Liu, B. (2021). The economics of investing in early childhood: Importance of understanding the science of scaling. In The Scale-Up Effect in Early Childhood and Public Policy (pp. 76-97). Routledge.

Zou, R., Tiemeier, H., van der Ende, J., Verhulst, F. C., Muetzel, R. L., White, T., . . El Marroun, H. (2019). Exposure to maternal depressive symptoms in fetal life or childhood and offspring brain development: A population-based imaging study. The American Journal of Psychiatry, 176(9), 702-710.

Publisher's note Springer Nature remains neutral with regard to jurisdictional claims in published maps and institutional affiliations.

\section{Authors and Affiliations}

\section{Richard E. Tremblay ${ }^{1,2}$}

Richard E. Tremblay

richard.ernest.tremblay@umontreal.ca

1 Departments of Pediatrics and Psychology, University of Montreal, Montreal, QC, Canada
School of Public Health, University College Dublin, Dublin, Ireland 